\title{
Geological factors for hazardous debris flows in Hoser, central Taiwan
}

Hongey Chen · Ding-Yi Su

\begin{abstract}
By means of an onsite investigation, the largest debris flow in Taiwan's history is analyzed in this paper. A heavy rainfall of $1,748 \mathrm{~mm} /$ day occurred during typhoon Herb in the Hoser area at the end of July 1996. Aerial photographic assessment and observations of geological and geomorphological features have contributed to our understanding of this massive destruction. Mechanisms of the hazardous debris flow are explored and discussed. Data revealed that the rock discontinuities were a major factor in the voluminous loose materials in the debris flows. The heavy and rapid rainfall instantly transported massive amounts of debris flow materials into the center, and then quickly funneled them to the lower parts of gullies. The heavy slurry became an effective cutting device to erode the side walls and move large quantities of the debris materials to the end of the gullies.
\end{abstract}

Keywords Hazard Debris flow - Discontinuity Geomorphology
River. It makes up a total area of around $10 \mathrm{~km}^{2}$. No. 1 and No. 3 gullies were selected for the present investigation. The elevation of the study area ranges from 820$1,150 \mathrm{~m}$ above sea level. It is a rugged hilly area with slopes of $15-45^{\circ}$.

Typhoon Herb caused flash flood events and huge massive material movements. Debris flows transported eroded materials down to the bottom of the gullies. Disintegrated materials flowed out from the upper and middle parts of the gullies, just behind the villages (Chen and others 1999; Chen 2000).

Conditions for debris flows include the local geomorphology, geological characteristics, quantity of geomaterials, and degree of saturation by groundwater (Johnson and Rodine 1984; VanDine 1985; Baldwin and others 1987; Takahashi 1991). Geomorphological studies of this area have been based on aerial photography from 1980 to 1996. Also, detailed onsite observations in terms of geology and geomorphology provide a better understanding of the origin of the debris flows in the study area. Topographical changes in the gully beds and mountain slopes are herein compared to aerial photography before and after the debris flows. Discontinuities of rocks and slope stability are investigated in detail in the present study.

\section{Geological condition}

Typhoon Herb unleashed a great volume of precipitation, at the rate of $1,748 \mathrm{~mm} / \mathrm{day}$, in the Hoser area at the end of July 1996. Without warning, an enormous flood redeposited huge quantities of material from devastating liquid flows. This violent storm resulted in serious damage and loss of property, totaling around 600 million US dollars in central Taiwan.

Hoser is in the southern part of Nantou county in central Taiwan (Fig. 1), along the western banks of the Hoser

Received: 28 June 2000 / Accepted: 11 December 2000 Published online: 11 April 2001

(C) Springer-Verlag 2001

H. Chen ( $₫) \cdot$ D.-Y. Su

Department of Geosciences, National Taiwan University,

245 Choushan Road, Taipei, Taiwan

E-mail: hchen@ccms.ntu.edu.tw

Fax: +886-223636095
The rock types along the western sector of the Hoser River consist of massive shale, sandy shale and fine interbeds of sandstone and shale. They belong to the Hoser Formation of Miocene age (Ho 1986). It is easy to find some flexural slip folds and relative displacements in the rock formation. Cementation is not very good in various rocks, and appears highly fractured.

Figures 2 and 3 show discontinuities caused by bedding and jointing distributed on both side walls of the studied gullies. The axis of the Hoser anticline passes through the center of the study area in a north-south direction. Different sets of discontinuities have intervals varying from $10 \mathrm{~cm}$ to $1 \mathrm{~m}$. The strike of the bedding in the western part of the study area ranges from $\mathrm{N} 31^{\circ} \mathrm{E}$ to $\mathrm{N} 42^{\circ} \mathrm{E}$, and the dip from 60 to $68^{\circ}$ towards the northwest. The three sets of joints are (1) $\mathrm{N} 30^{\circ} \mathrm{E}$ with a southerly dip of $85^{\circ}$, (2) $\mathrm{N} 35^{\circ} \mathrm{W}$ with a northerly dip of $40^{\circ}$, and (3) $\mathrm{N} 70^{\circ} \mathrm{W}$ with a southerly dip of $50^{\circ}$. Calcite and quartz commonly 


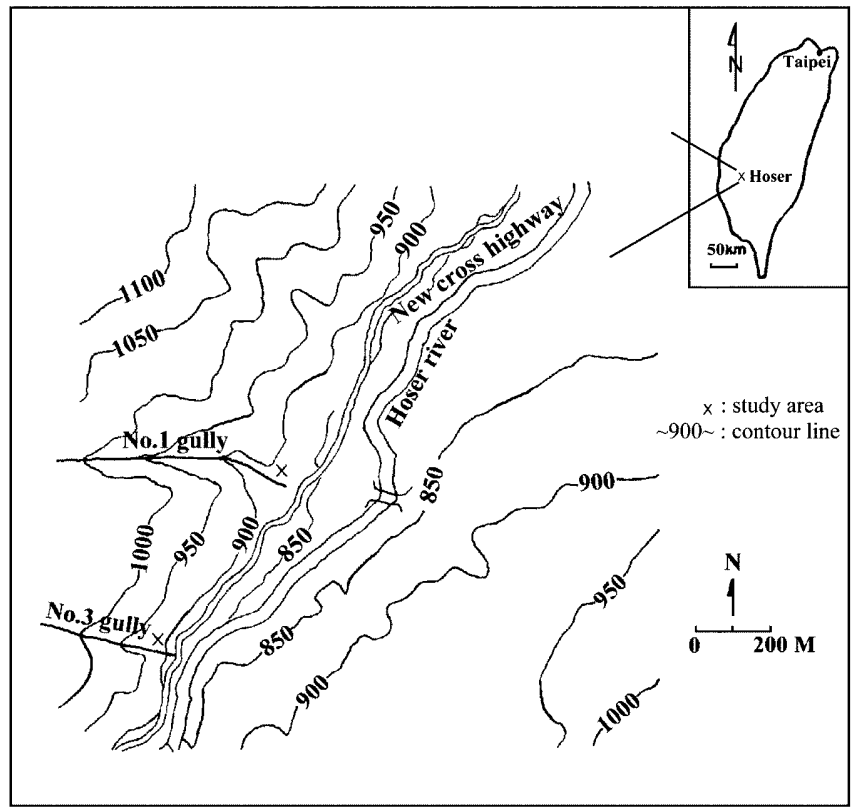

Fig. 1

The study area Hoser is located in the middle part of Taiwan

fill the discontinuities. The densely distributed discontinuities cut up massive rocks and form huge volumes of fractured rocks and debris on various slopes, waiting for movement.

\section{Aerial photography}

Photographs taken in five periods, namely, 1980, 1985, 1988, 1993 and 1996 were used to compare the consecutive changes of erosive forces in the Hoser area. The overall geomorphology of the study area can be readily traced by these aerial photographs. The existing slope collapses on the ground surface, and the gully channels can also be quickly traced (Rib and Liang 1978; Shlemon and others 1987).

Symbols 1-1 to $4-1$ of the same places on the aerial photographs of the study area were used to highlight the specific changes in topography in each period. The first digit of the hyphenated number pairs (1-1, 2-1, 3-1, etc.) designates the different areas. The second digit represents the various locations and geomorphological features being compared.

\section{0}

The mouth of No. 1 gully shows little sign of deposition or movement of material. Vegetation and trees were naturally distributed in their evidently original state on the slope. The uphill slope areas of the gully show no deposits or collapses on either side. On the western banks of the Hoser River, some features are nearly too small to distinguish in

Fig. 2

Around four sets of discontinuities attitudes shown on both side walls of No. 1 gully in the Hoser area

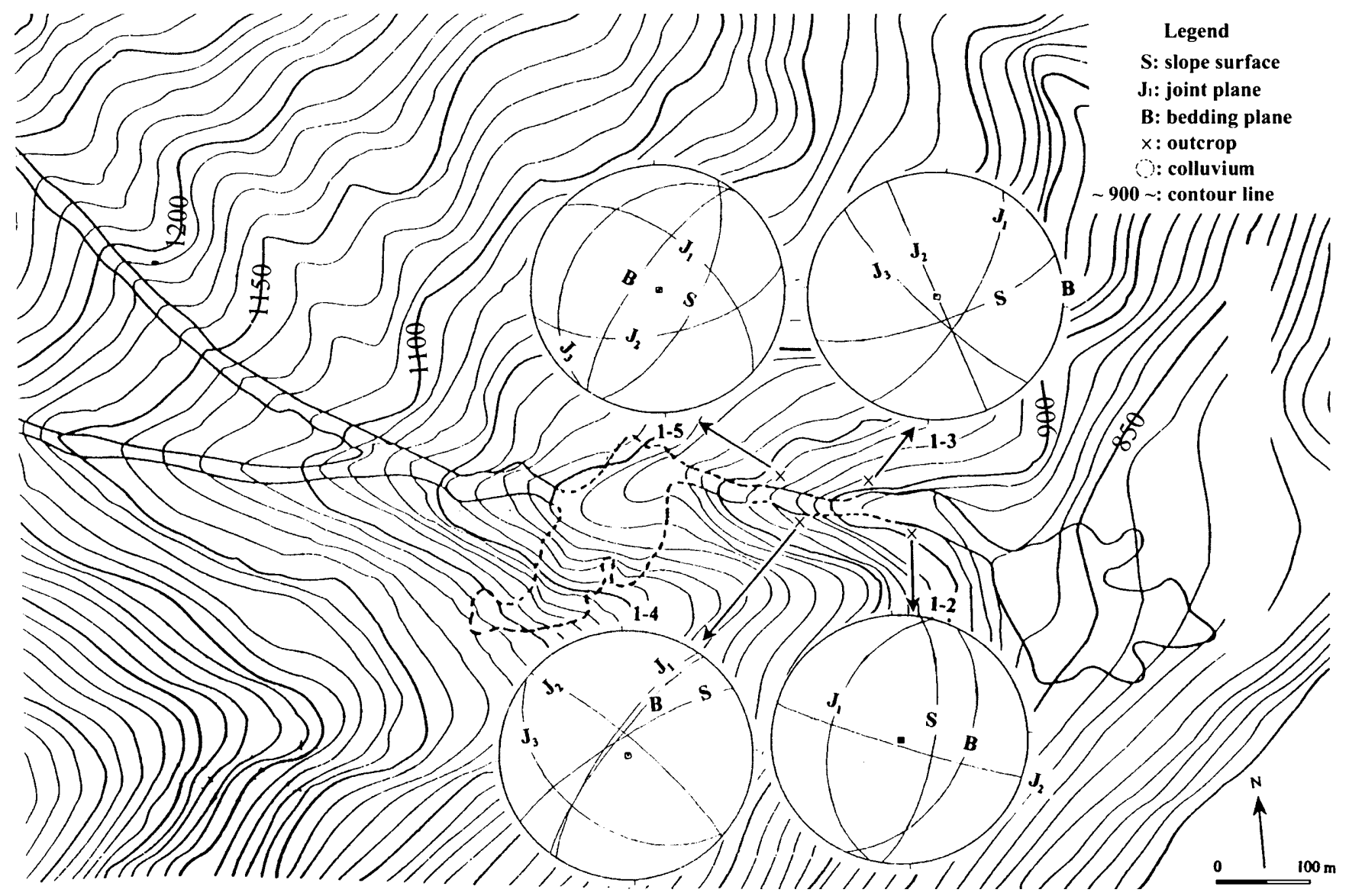




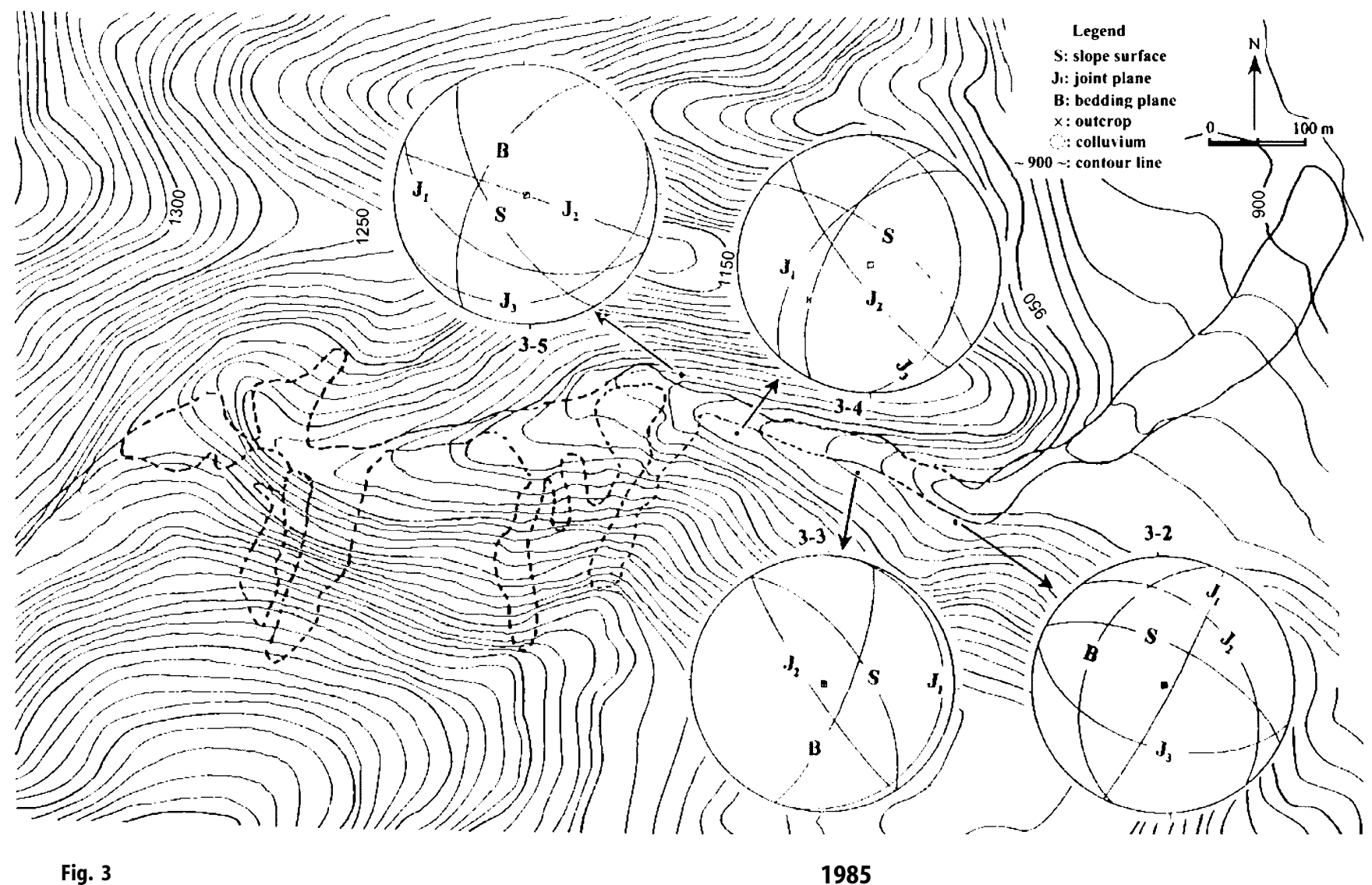

The attitudes of three sets of discontinuities displayed on both side walls of No. 3 gully in the Hoser area

the photographs (Fig. 4). No. 1 gully and the other watershed divide are very clear. The lateral lobes in the study area have not yet been produced. A delta fan at the mouth of the gully was obviously formed long ago. Many farm fields have already been produced on the slope. No. 3 gully also shows no evidence of deposited material or collapsed conditions.

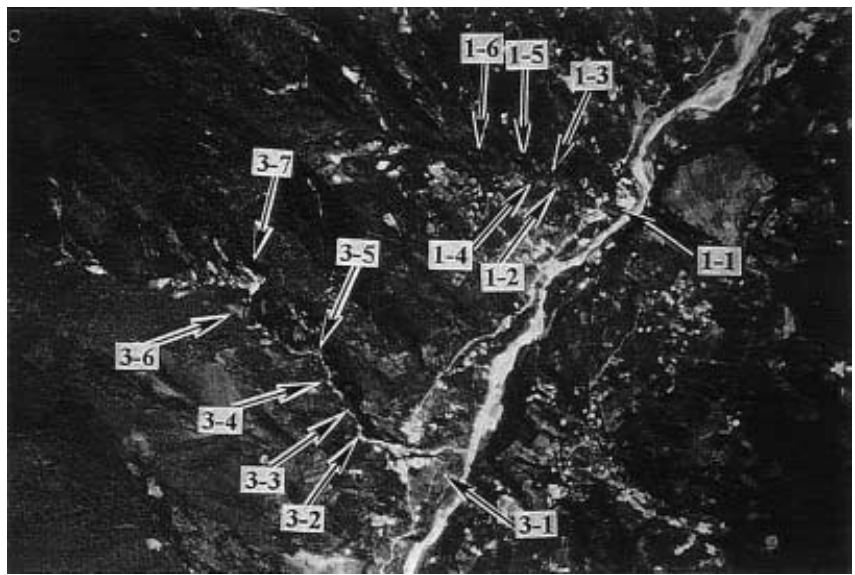

Fig. 4

Aerial photograph of the Hoser area (including No. 1 and No. 3 gullies) in 1980 (used as reference)
There are no obvious changes in topography after 5 years at No. 1 and No. 3 gullies (Fig. 5). Compared to Fig. 4, no evidence of erosion and deposited material appeared in Fig. 5.

\section{8}

The areas in the middle parts of No. 1 and No. 3 gullies have changed slightly in their topography after 8 years (Fig. 6). The farm areas around both gullies have obviously increased in size and number.

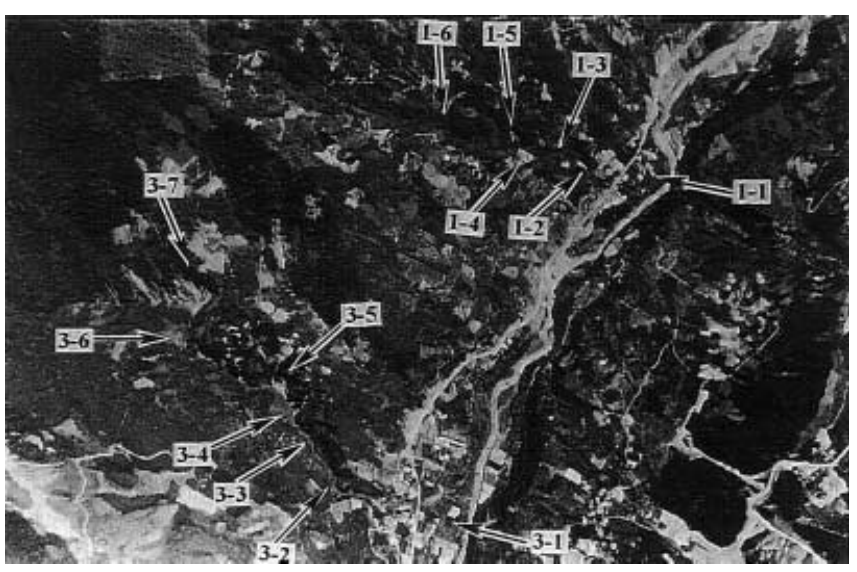

Fig. 5

Aerial photograph of the Hoser area (including No. 1 and No. 3 gullies) in 1985, used for comparison with features in 1980 


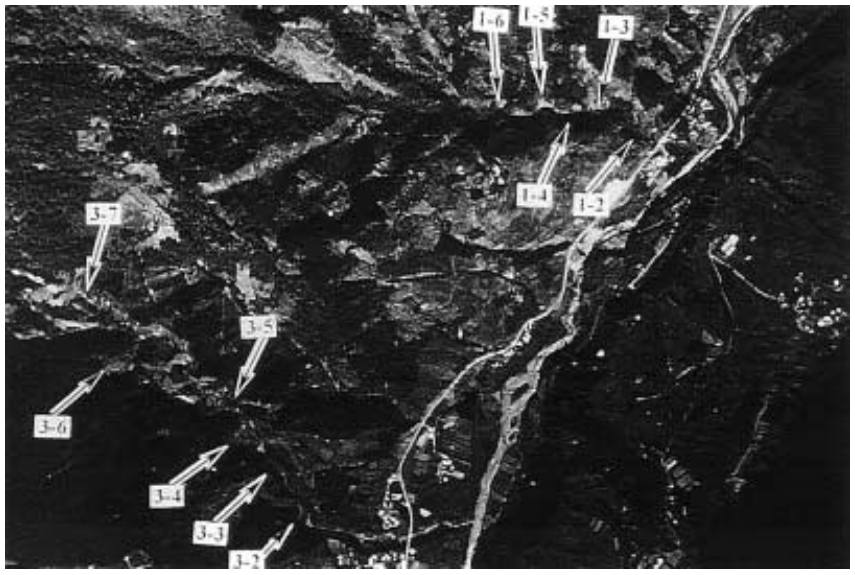

Fig. 6

Aerial photograph of the Hoser area (cf. No. 1 and No. 3 gullies) in 1988. This can be compared with features in 1985

\section{3}

The vegetation changed slightly uphill of No. 1 and No. 3 gullies (labels 1-2, 1-3, and 3-2, 3-5, respectively). The shape of the gullies was only altered a little (Fig. 7). Neither was there any evidence of erosion or material movement in the gully (labels $1-4,1-5$ and 3-6, 3-7). The farm areas near the gullies have increased in number and size at the detriment of native plants, thereby increasing the risk of erosion.

\section{6}

After typhoon Herb, the morphology changed dramatically (Fig. 8). The original vegetation was removed by cutting and erosion of the chaotic debris flow materials. The gully channels became wider than in 1993. The gullies now obviously show deposited materials and huge material movement. The original areas of No. 1 and No. 3 gullies have had large collapses on both sides of the gullies. Big lobes have formed in the collapsed areas. The mouths have received masses of deposited geomaterials, forming new

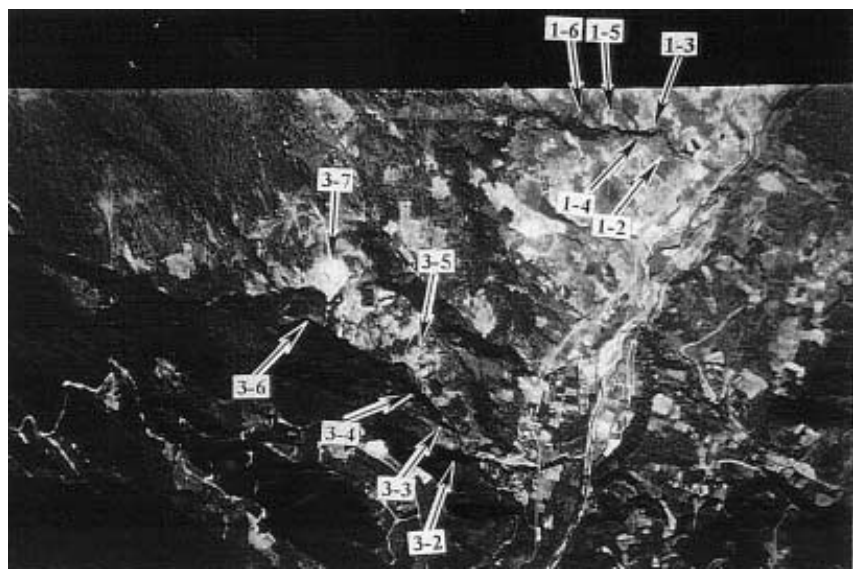

Fig. 7

Aerial photograph of the Hoser area (cf. No. 1 and No. 3 gullies) in 1993. Comparison with 1988 reveals a minor increase in farmland

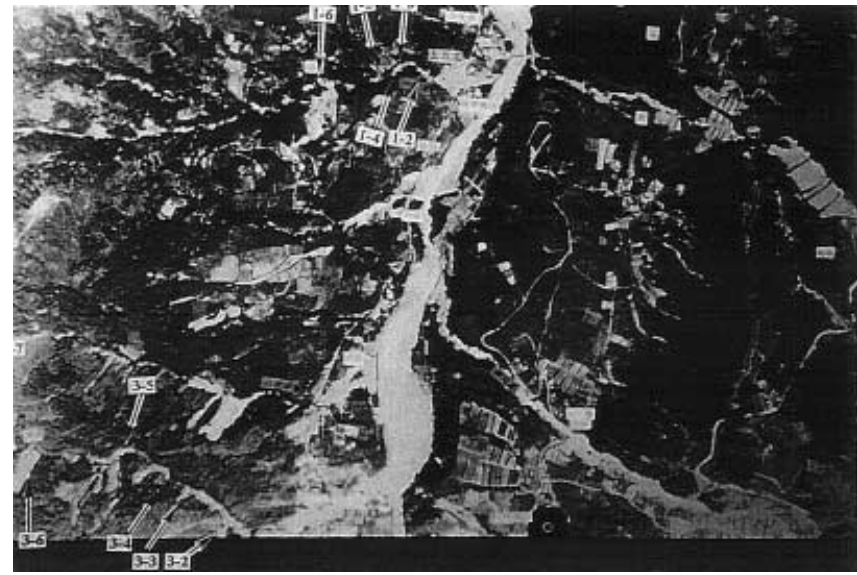

Fig. 8

After typhoon Herb, widespread devastation was evident. Obvious collapses were clearly observed in the aerial photograph of 1996

alluvial deltas. The lengths, widths and depths of the deposits in the gullies have increased dramatically. The various photographs from the five different periods demonstrate that the gully shapes and widths changed little before the debris flow hazard at the end of the 15 years. A very complex network was formed by the tributary streams on both sides of the Hoser River over this 15-year period. The morphology of No. 1 and No. 3 gullies also totally changed after typhoon Herb. Figure 8 clearly shows that the widths of both gullies appear to be 5 times what they were in 1993.

The watershed areas on the mountain sides above both gullies (Nos. 1 and 3) experienced a large number of collapses - particularly at the heads of the gullies. Steep scars on both sides of both gullies have become evident, and developed over the whole distance. The resulting widened valleys were clearly visible in the aerial photographs. The mouths of both gullies have widened, and the delta fans have been much enlarged. The small lateral lobes have been eroded and combined with the main (Nos. 1 and 3) gullies. Many trees were swept away from their original locations. Villages along the Hoser River were eradicated in this major disaster.

\section{Geomorphology}

The components of debris flows are found mainly in three distinct areas. The main triggering debris flow material comes from the area of origin. The second major component - the flow area - is composed of material moving from the upper part, combining with water in its flow to the bottom of the gully. The terminal resting location of formerly moving geomaterial forms the depositional area (Fyleming and others 1989), which normally shows a deltafan shape. Deposited geomaterials are typically described as coarse, poorly sorted, unstratified and unconsolidated (Costa and Jarrett 1981; Johnson and Rodine 1984; Shlemon and others 1987). 


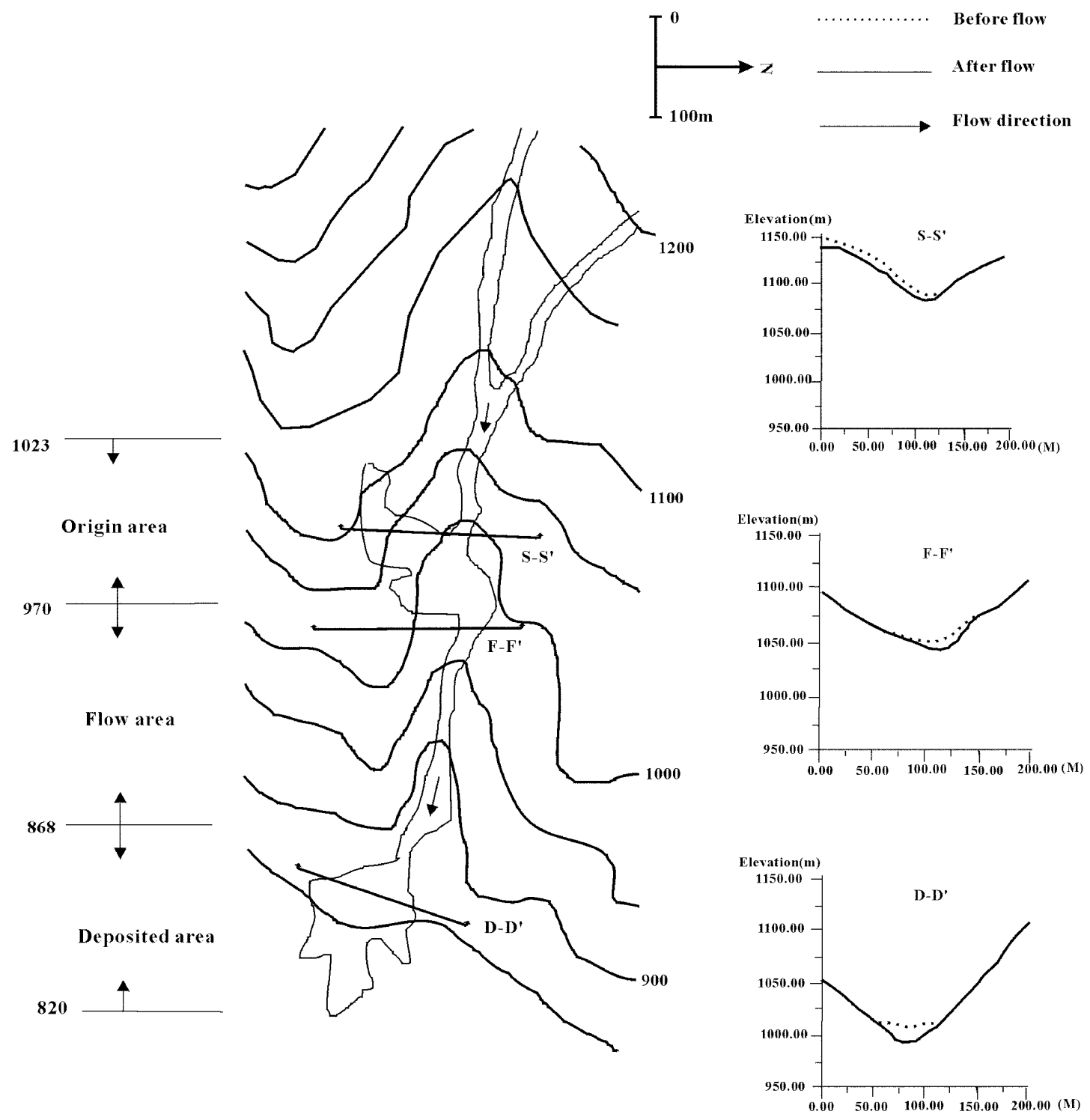

Fig. 9

A cross section of No. 1 gully, showing trends in elevation before and after hazardous flow in the Hoser area

Debris flows occurring as slope deposits are set in motion by massive runoff. The deposition of levees may begin at $15^{\circ}$. The slope gradient in the deposited area tends to be gentle. Upper-gully geomaterial deposits must reach a sufficient thickness to support the initiation of a debris flow (Campbell 1974; Baldwin and others 1987). Sufficient precipitation is all that is necessary to set off the triggering mechanisms of a devastating debris flow (Eyles 1979; Nielsen 1984).

Understanding the respective contributions of these three areas of debris flows can help in the articulation and comprehension of the hazardous area under study. The cumulative deposits on the river bank have increased gradually, as demonstrated by aerial photographs spanning the last 15 years in the Hoser River region. Each debris flow formed a lobe as it filled a concave area which had been left by the preceding lobes.

In observations at the site, the cohesion of the geomaterial appears to be quite weak to nonexistent. The geomaterial in an initial flow and after-flow condition tends to be very difficult to differentiate at one and the same site. The angular and rounded form of the rock fragments and boulders provides a critical clue about whether the material is part of an initial flow or after flow. By means of field observations, it is possible to determine whether the rock fragments are historically rounded or recently angular. These observations show whether the original geomaterials are freshly broken in situ, or have already been transported for a long distance in the gully from higher locations.

\section{Site condition}

The area of origin forms a hollow topography uphill of No. 1 and No. 3 gullies, and was formed by the drag fold of a syncline structure. The diameter of this hollow is $23 \mathrm{~m}$, and contains collapsed material from both sides of the gullies. Erosion reaches about 1-5 $\mathrm{m}$ in the channels of both gullies. The thickness of the deposited material is around $1.5 \mathrm{~m}$. 
Table 1

Geomorphological features of the hazardous debris flow along the profiles of No. 1 and No. 3 gullies in the Hoser area

\begin{tabular}{|c|c|c|c|c|c|c|}
\hline Gully & Area & $\begin{array}{l}\text { Elevation } \\
(\mathrm{m})\end{array}$ & $\begin{array}{l}\text { Geomorphological } \\
\text { features }\end{array}$ & $\begin{array}{l}\text { Slope } \\
\text { grade } \\
\left({ }^{\circ}\right)\end{array}$ & $\begin{array}{l}\text { Gully } \\
\text { shape }\end{array}$ & Distribution \\
\hline \multirow{2}{*}{ No. 1} & Flow & $970-868$ & $\begin{array}{l}\text { The eroded area is much } \\
\text { bigger than the original } \\
\text { part. Both side walls show } \\
\text { marked erosion and } \\
\text { undercutting }\end{array}$ & 18 & $\begin{array}{l}\text { V shape before } \\
\text { hazard; U shape } \\
\text { after hazard }\end{array}$ & Erosion $(4 \mathrm{~m})$ \\
\hline & Deposition & $868-820$ & $\begin{array}{l}\text { Large deposition area } \\
\text { covers the old delta fan }\end{array}$ & 9 & Alluvium & Deposition $(11 \mathrm{~m})$ \\
\hline \multirow[t]{2}{*}{ No. 3} & Origin & $1,152-1,002$ & $\begin{array}{l}\text { Both side walls in the } \\
\text { uphill areas show serious } \\
\text { collapse. The lower parts } \\
\text { of this area show strong } \\
\text { erosion }\end{array}$ & 15 & $\begin{array}{l}\text { V shape before } \\
\text { hazard; U shape } \\
\text { after hazard }\end{array}$ & Erosion $(6 \mathrm{~m})$ \\
\hline & Deposition & $945-891$ & $\begin{array}{l}\text { A substantial amount of } \\
\text { deposited material covers } \\
\text { the old alluvium }\end{array}$ & 8 & Alluvium & Deposition (8 m) \\
\hline
\end{tabular}

The 34 profiles (spacing: $25 \mathrm{~m}$ ) were used for section analysis in No. 1 gully. This method enabled a better comprehension of the changes of topography before and after the collapse along the gully (Fig. 9). The gully showed a V shape before the hazard at elevations of 1,023 to $970 \mathrm{~m}$. The slope gradient before collapse was $18^{\circ}$ (Table 1 ). The gully containing the debris deposits shows a U shape after the collapse, and the slope gradient averages $15^{\circ}$. The results of the comparison of the topography demonstrate that the gully was eroded downwards and outwards to both sides (Fig. 10). This also changed the cross section from a V shape to more of a U shape. Erosion cuts generally $6 \mathrm{~m}$ deep into the topography. The deepest area was about $11 \mathrm{~m}$. Some parts of the flow section still appear in an eroded condition, and others appear newly deposited at elevations of 970 and $868 \mathrm{~m}$. The slope gradient changed from $20^{\circ}$ before the hazard to $17^{\circ}$ thereafter. These conditions signal a potential flow section in a future deluge.

The depositional sections of the gully at elevations of 868 to $820 \mathrm{~m}$ formed a $\mathrm{U}$ shape before the debris flow. This shape was retained after the debris flow. The slope gradient is very gentle, varying from 11 to $9^{\circ}$. The thickness of the depositional area was about $11 \mathrm{~m}$ in this case. The maximum thickness increased to $17 \mathrm{~m}$.

The 71 profiles (spacing: $25 \mathrm{~m}$ ) were used for section analysis at No. 3 gully (Fig. 11). The gully formed a V shape before the hazard at elevations of 1,152 to $1,002 \mathrm{~m}$. The slope gradient before the hazard was $19^{\circ}$ (Table 2 ). The gully forming the debris deposit has a $U$ shape in its cross section after the collapse. Here the slope gradient averages $15^{\circ}$. Comparison of the topography of No. 3 gully reveals that the gully was eroded downwards and outwards to both sides (Fig. 12). Erosion reached $6 \mathrm{~m}$ on average, the deepest area being about $9 \mathrm{~m}$.

The flow section still appears in an eroded or deposited state at elevations of 1,002 to $945 \mathrm{~m}$. The slope gradient decreased from $13^{\circ}$ before, to $11^{\circ}$ after the hazard. This flow section contains serious downward cutting. However, all parts of the gully section at 945-m elevation show depositional features. This local region is now defined as the depositional section. The erosional cutting here is about $6 \mathrm{~m}$. The lower sections at elevations of 945 to $891 \mathrm{~m}$ were U shaped before the debris flow. This shape was retained after the debris flow. The slope gradient becomes very gentle $\left(10\right.$ to $\left.8^{\circ}\right)$, and thickness is around $8 \mathrm{~m}$. The maximum thickness is about $15 \mathrm{~m}$ at these sites.

The volume of deposited geomaterial from the debris flow in the channel of No. 1 gully was about $490,350 \mathrm{~m}^{3}$. A total of $48,020 \mathrm{~m}^{3}$ was deposited in the middle part of the gully, and another $442,330 \mathrm{~m}^{3}$ in the delta fan between the mouth of the gully and the Hoser River. In No. 3 gully, the volume of deposits was about $985,572 \mathrm{~m}^{3}$. A total of $221,547 \mathrm{~m}^{3}$ was deposited in the middle part of this gully, the value increasing to around $764,025 \mathrm{~m}^{3}$ in the delta fan. This area is also located between the mouth of the gully and the Hoser River.

Close observation of the debris flow can demonstrate whether the sources of geomaterial are from freshly broken, in-situ materials or from other older materials. Some chaotic materials have already been transported a long distance in the gully from higher locations. Mixtures of the deposited material include rock fragments and fine particles. The size of big boulders is about 1 to $4 \mathrm{~m}$. Their shapes appear subangular to angular, and 

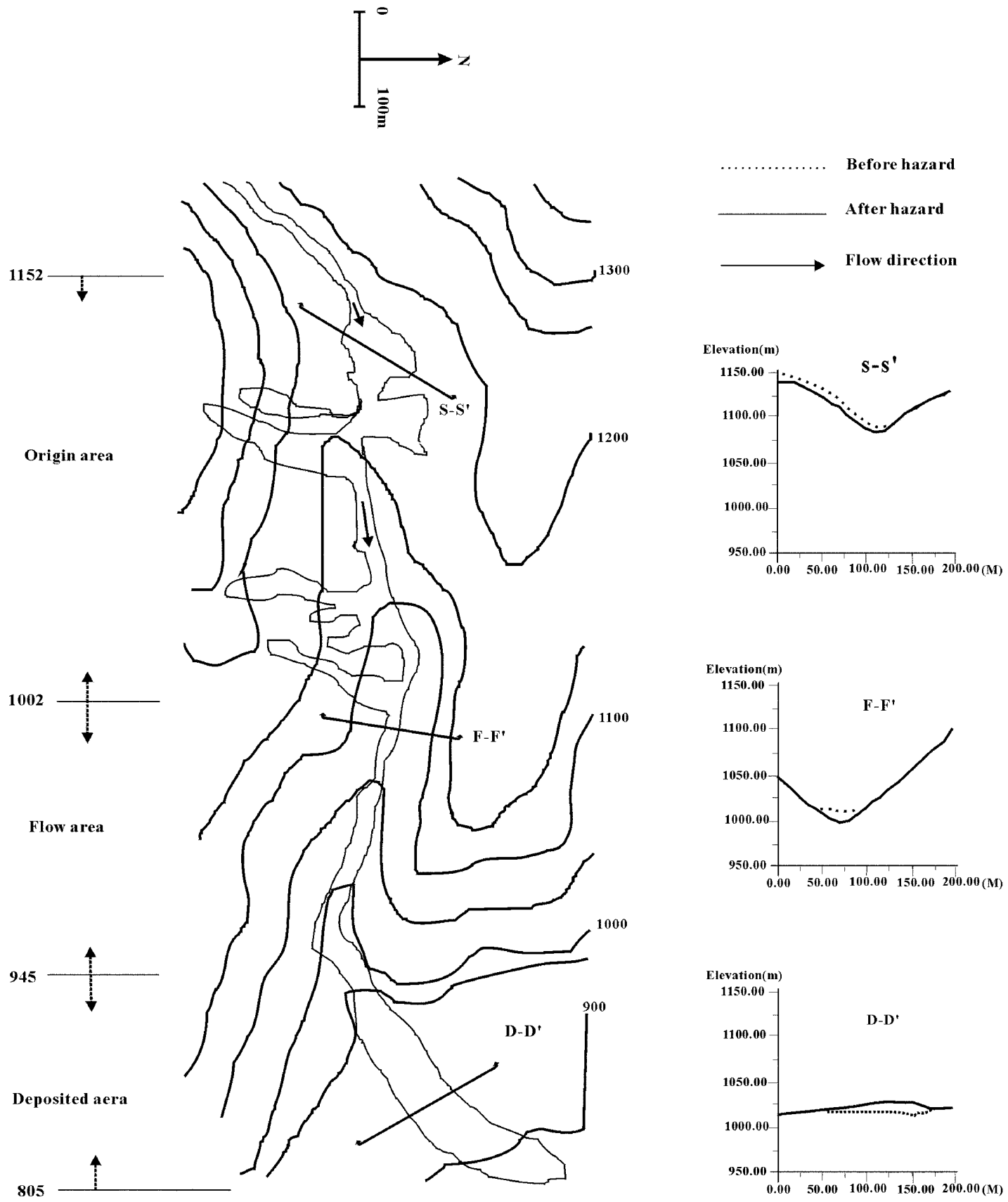

Fig. 10

A cross section of No. 3 gully, showing trends in elevation before and after hazardous flow in the Hoser area

the lithology is fresh. The gully beds are normally empty of water. The slope gradient varies from around 30 to $60^{\circ}$.

\section{Geomaterial properties}

The geomaterial of the debris flow in the gully used in the model test was reconstituted with field material. This was done in laboratory experiments, by using the socalled modified weight replacement method with scaled-

down particles with maximum grain sizes of $1.5,1.0$, and 0.5 in (38.1, 25.4, and $12.7 \mathrm{~mm}$, respectively). The main constraint of this method is to insure that the geomaterials have similar unit weight and porosity as those in situ.

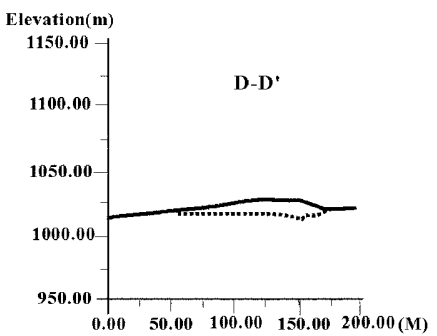
Su (1998) excavated three and five pits measuring $1 \times 1 \times 1 \mathrm{~m}$ in both study areas. This author collected in-situ samples for assessments of physical properties in the upper, middle and lower parts of each pit in the depositional area. The soil classification followed the unified soil classification scheme. These results demonstrated that each deposit in the individual study areas had similar physical properties (Table 3). To determine shear strengths of the gully sides, a direct shear test of the multistage method was used to test the geomaterials from the various discontinuities on both sides of the gully (Chen and others 1995). 

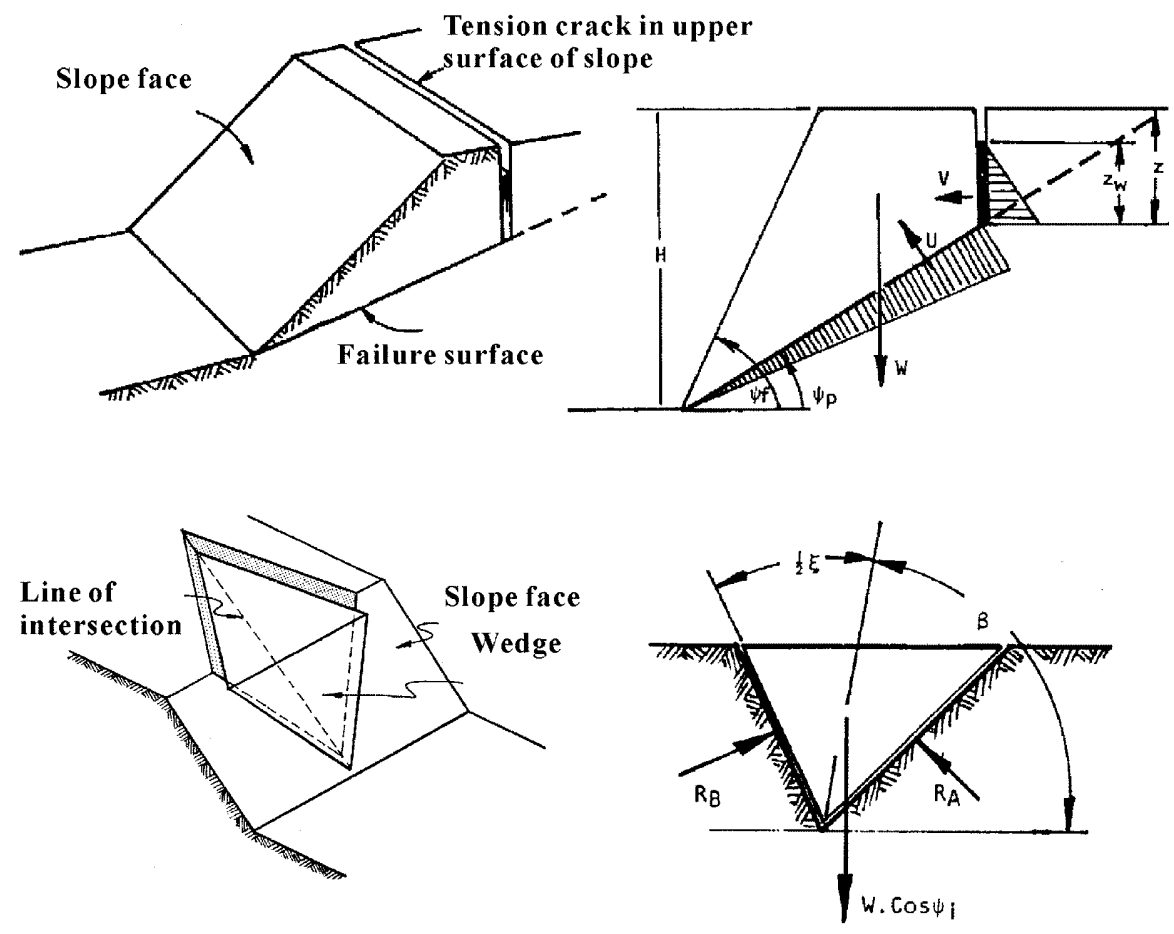

Fig. 11

Geometry of the dip-slope and the wedgeslope models (after Hoek and Bray 1981)

The experimental tests on discontinuities included assessments of schistosity, bedding and joints. In order to simulate the in-situ conditions, a large direct shear box of $30 \times 30 \times 15.3 \mathrm{~cm}$ was used.

The geomaterial samples were taken for classification from the three different parts. In general, it has been found that the geological characteristics of the gully, and the mechanical behavior of the geomaterials are factors which affect the debris flow.

All samples taken from the test pits in No. 1 gully have no intrinsic cohesion, and the friction angle varies from 34 to $36^{\circ}$. However, under saturated conditions the friction angle fluctuates in the range 30 to $31^{\circ}$. In No. 3 gully, the values vary from 34 to $36^{\circ}$ and, under saturated conditions, from 29 to $31^{\circ}$.

In No. 1 gully, the shear strength of the discontinuities plane was $29-41^{\circ}$ under dry conditions, and $25-33^{\circ}$ in the saturated state. In No. 3 gully, it is $32-38^{\circ}$ under dry conditions, and $27-34^{\circ}$ in the saturated state. These discontinuities on the exposed gully sides form a

Table 2

Test result of physical properties of deposits in No. 1 and No. 3 gullies of the Hoser area. $P_{1}$ Pits in No. 1 gully. $P_{3}$ Pits in No. 3 gully

\begin{tabular}{|c|c|c|c|c|c|c|}
\hline Area & Pit no. & $\begin{array}{l}\text { Gravel } \\
\text { content } \\
(>2 \mathrm{~cm}) \\
(\%)\end{array}$ & $\begin{array}{l}\text { Water } \\
\text { content } \\
(\%)\end{array}$ & $\begin{array}{l}\text { Unit } \\
\text { weight } \\
\left(\mathrm{t} / \mathrm{m}^{3}\right)\end{array}$ & $\begin{array}{l}\text { Void } \\
\text { ratio }\end{array}$ & $\begin{array}{l}\text { Degree of } \\
\text { saturation } \\
(\%)\end{array}$ \\
\hline \multirow[t]{6}{*}{ Hoser } & $P_{1}-1$ & 89.4 & 3.7 & 2.11 & 0.45 & 32.1 \\
\hline & $P_{1}-2$ & 81.8 & 4.3 & 1.79 & 0.51 & 28.5 \\
\hline & $P_{1}-3$ & 77.7 & 5.7 & 1.85 & 0.48 & 30.4 \\
\hline & $\mathrm{P}_{3}-1$ & 78.5 & 4.6 & 1.94 & 0.46 & 29.7 \\
\hline & $\mathrm{P}_{3}-2$ & 72.7 & 3.8 & 2.05 & 0.41 & 28.1 \\
\hline & $\mathrm{P}_{3}-3$ & 75.1 & 3.4 & 1.83 & 0.43 & 25.4 \\
\hline
\end{tabular}

potential wedge model. Table 4 shows the measured shear strengths on the contact plane of the discontinuities (Su 1998).

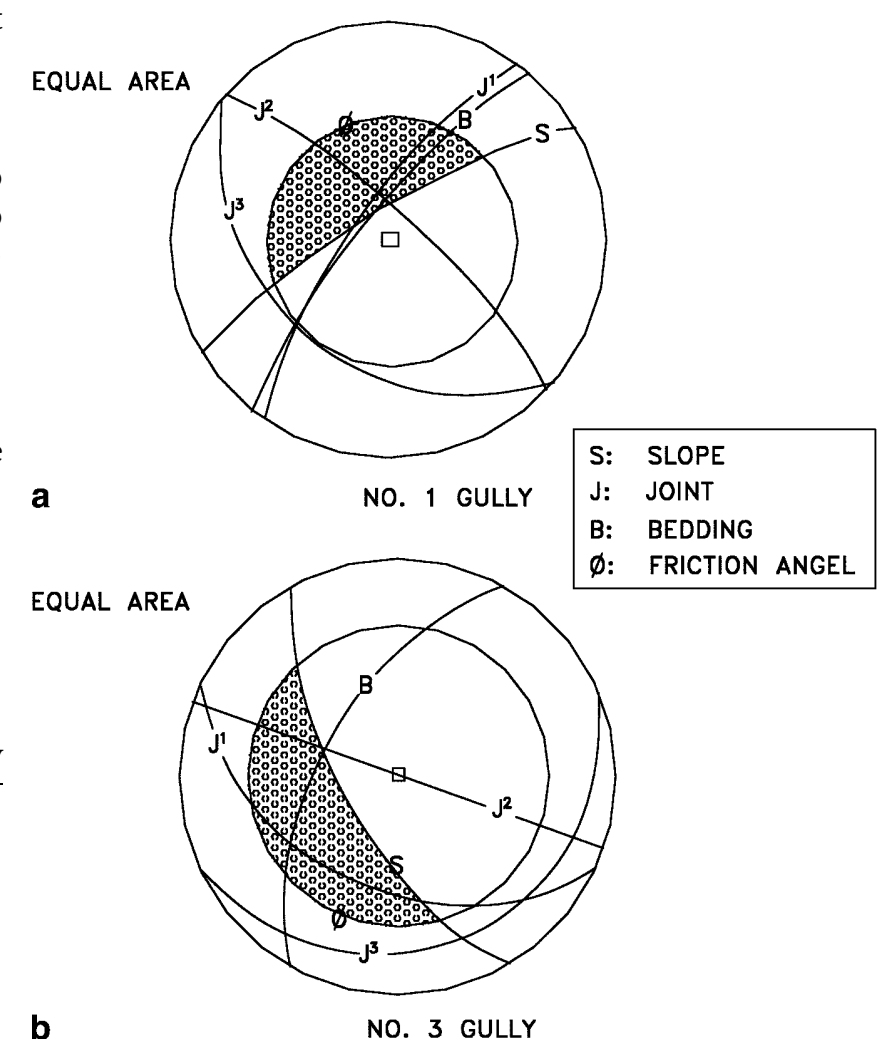

Fig. 12a, b

Stereonet analysis of a No. 1, and b No. 3 gullies, with dotted areas indicating the potentially unstable sectors 
Table 3

Results of the shear strength of discontinuity in No. 1 and No. 3 gullies of Hoser area (no intrinsic cohesion appeared in discontinuity). $H$ Hoser; $j$ joint plane; $b$ bedding plane; $d$ air dry; $w$ saturated

\begin{tabular}{|c|c|c|c|c|c|}
\hline Area & Discontinuity & $\begin{array}{l}\text { Sample } \\
\text { condition }\end{array}$ & Sample no. & $\begin{array}{l}\text { Friction } \\
\text { angle }\left({ }^{\circ}\right)\end{array}$ & Remark \\
\hline \multirow[t]{12}{*}{ Hoser } & \multirow[t]{4}{*}{ Bedding plane } & \multirow[t]{2}{*}{ Air dry } & $12 \mathrm{Hbd}$ & 32.0 & No. 1 gully \\
\hline & & & $32 \mathrm{Hbd}$ & 29.0 & No. 3 gully \\
\hline & & \multirow[t]{2}{*}{ Saturated } & $12 \mathrm{Hbw}$ & 31.5 & No. 1 gully \\
\hline & & & $32 \mathrm{Hbw}$ & 24.0 & No. 3 gully \\
\hline & \multirow{8}{*}{ Joint plane } & \multirow[t]{4}{*}{ Air dry } & $13 \mathrm{Hjd}$ & 39.0 & \multirow[t]{2}{*}{ No. 1 gully } \\
\hline & & & $14 \mathrm{Hjd}$ & 41.0 & \\
\hline & & & $32 \mathrm{Hjd}$ & 34.0 & \multirow[t]{2}{*}{ No. 3 gully } \\
\hline & & & $33 \mathrm{Hjd}$ & 38.0 & \\
\hline & & \multirow[t]{4}{*}{ Saturated } & $13 \mathrm{Hjw}$ & 33.0 & \multirow[t]{2}{*}{ No. 1 gully } \\
\hline & & & $14 \mathrm{Hjw}$ & 32.5 & \\
\hline & & & $32 \mathrm{Hjw}$ & 28.0 & \multirow[t]{2}{*}{ No. 3 gully } \\
\hline & & & $33 \mathrm{Hjw}$ & 34.0 & \\
\hline
\end{tabular}

\section{Stability condition}

Stability analyses in this paper were conducted to understand the potential behavior of slopes on both sides of the gully. The analytical methods include discontinuities analyses and safety factor calculation. The stability analysis makes use of plane-failure and wedge-failure methods. The basic results on a potentially unstable slope are determined from a stereonet analysis.

The quantitative determination of the stability of a slope using any of the accepted methods should be based on a knowledge of the geological structure of the area and the geomorphological history of the land use (Graham 1984; Bromhead 1986). The safety factor is normally considered to represent the average reserve ability of the profile to resist the gravity forces and other external forces which act on the geomaterial mass of the slope.

\section{Safety factor calculation}

Figure 13 shows the geometric types of dip-slope and wedge-slope models. Both potentially unstable models

Table 4

The results of safety factor for the outcrop on both sides of No. 1 and No. 3 gullies. $D$ Dry condition, $S$ saturated condition, $\theta$ slope grade of gully, $\phi$ friction angle, $F$ safety factor

\begin{tabular}{|c|c|c|c|c|c|}
\hline Gully & Sample no. & $\begin{array}{l}\theta \\
\left({ }^{\circ}\right)\end{array}$ & $\begin{array}{l}\phi \\
\left(^{\circ}\right)\end{array}$ & $\mathrm{F}$ & Remark \\
\hline \multirow[t]{8}{*}{ No. 1} & $112 \mathrm{D}$ & 48 & 32.0 & 1.11 & \multirow[t]{2}{*}{ Plane failure } \\
\hline & $112 S$ & 48 & 31.5 & 0.97 & \\
\hline & $122 \mathrm{D}$ & 46 & 32.0 & 1.64 & \multirow[t]{2}{*}{ Stable } \\
\hline & $122 S$ & 46 & 32.5 & 1.24 & \\
\hline & $133 \mathrm{D}$ & 61 & 39.0 & 1.05 & \multirow[t]{4}{*}{ Wedge failure } \\
\hline & $133 S$ & 61 & 33.0 & 0.80 & \\
\hline & $144 \mathrm{D}$ & 72 & 41.0 & 1.14 & \\
\hline & $144 S$ & 72 & 32.5 & 0.70 & \\
\hline \multirow[t]{8}{*}{ No. 3} & $322 \mathrm{D}$ & 40 & 29.0 & 1.20 & \multirow[t]{2}{*}{ Plane failure } \\
\hline & $322 S$ & 40 & 24.0 & 0.97 & \\
\hline & $323 \mathrm{D}$ & 36 & 34.0 & 1.32 & \multirow[t]{6}{*}{ Wedge failure } \\
\hline & $323 S$ & 36 & 28.0 & 0.97 & \\
\hline & $344 \mathrm{D}$ & 49 & 31.5 & 1.38 & \\
\hline & $344 S$ & 49 & 27.0 & 0.92 & \\
\hline & $355 \mathrm{D}$ & 78 & 34.5 & 1.19 & \\
\hline & $355 S$ & 78 & 32.0 & 0.90 & \\
\hline
\end{tabular}

have quantified safety factors (Hoek and Bray 1981). The dip-slope formula is as follows:

$F=\frac{c \times A+\left(W \cos \psi_{\rho}-U-V \sin \psi_{\rho}\right) \times \tan \phi}{W \sin \psi_{\rho}+V \cos \psi_{\rho}}$

where $c$ is cohesion $\left(\mathrm{kN} / \mathrm{m}^{2}\right), \psi_{\rho}$ is failure angle $\left(^{\circ}\right), A$ is length of slip surface $(\mathrm{m}), W$ is weight of failure mass $(\mathrm{t} / \mathrm{m}), U$ is uplift force $(\mathrm{t} / \mathrm{m}), V$ is lateral water pressure $(\mathrm{t} / \mathrm{m})$, and $\phi$ is friction angle $\left({ }^{\circ}\right)$.

The wedge-slope formula is:

$F=\frac{\left(R_{a}+R_{b}\right) \tan \phi}{W \sin \varphi_{i}}=\frac{\sin \beta \times \tan \phi}{\sin \frac{1}{2} \xi \times \tan \varphi_{i}}$

where $R_{a}$ and $R_{b}$ are normal stress on mass $\mathrm{A}$ and mass $\mathrm{B}$, respectively, $\xi$ is intersected angle on mass $A$ and mass $B$, $\phi$ is friction angle, $\varphi_{i}$ is dip angle of intersection line of two discontinuities, and $\beta$ is tilt angle of wedge.

The present stability analysis includes the gully deposition besides both sides of the gully slope. For this, the infinite slope method is used. Its basic equation is as follows:

$F_{s}=\frac{\gamma_{s a t}-\gamma_{\omega}}{\gamma_{s a t}} \cdot \frac{\tan \phi}{\tan \theta}$

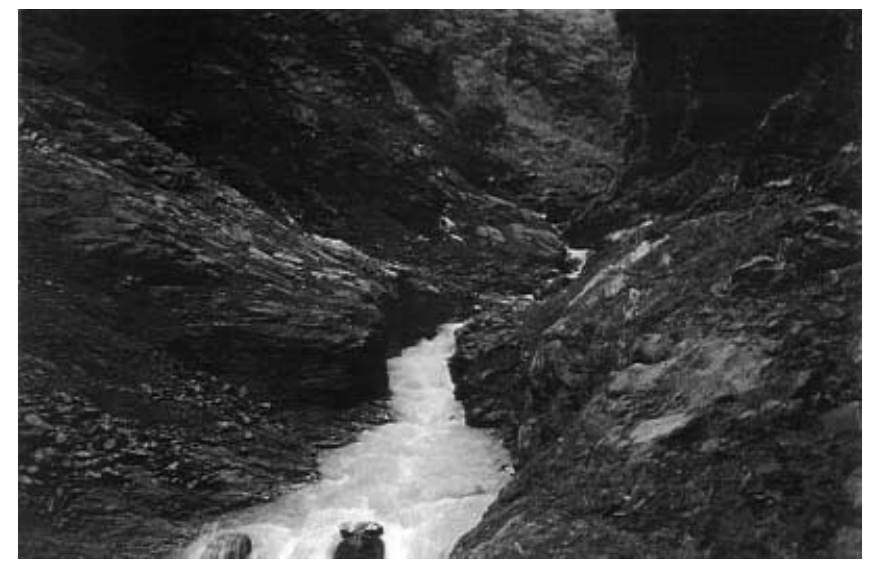

Fig. 13

The abrasive geomaterial came from the upper parts, and cut downwards and outwards at both sides of No. 1 gully after typhoon Herb 
where $\gamma_{\text {sat }}$ is saturated unit weight, $\gamma_{\mathrm{w}}$ is water unit weight, $\phi$ is friction angle, and $\theta$ is failure angle.

The above parameters of shear strength were taken from the laboratory tests and used to analyze the critical conditions for initiating a debris flow in the study areas.

\section{Discontinuities analysis}

The discontinuities analysis is based on a semiquantitative set of parameters, and has implications for the rock slope on both sides of gully. The geological attitude was measured by in-situ investigation, and plotted in a stereonet. The data include discontinuities of bedding, joints and diverse slope surfaces (Selby 1987; Priest 1992). The data sets comprise various geometric shapes, and set up the possibility of various potential failure models. These geometric types reveal themselves as potential failure models and clearly show a tendency for instability or even collapse of the slope.

\section{Stability results on outcrop}

Figure 14 displays the possible directions of block displacement, such as the dip-slope and wedge-slope models for No. 1 and No. 3 gullies. The shadow area shows the potentially unstable slopes.

The safety factor of the outcrop at sites $1-2,1-3$ and 1-4 on both sides of No. 1 gully displays a potentially unstable state in a saturated condition. The failure model includes plane, wedge and topple failures. This result indicates a good stability under normal dry conditions. When these slopes are saturated, however, the safety factor will fall below 1.0 (Table 5), and the slope will fail (Fig. 15A).

The safety factor of the outcrop at sites 3-2, 3-4 and 3-5 on both sides of No. 3 gully displays a potentially unstable state in the saturated condition. The failure model also includes plane, wedge and topple failure. These results are similar to those recorded for gully No. 1

(Fig. 15B).

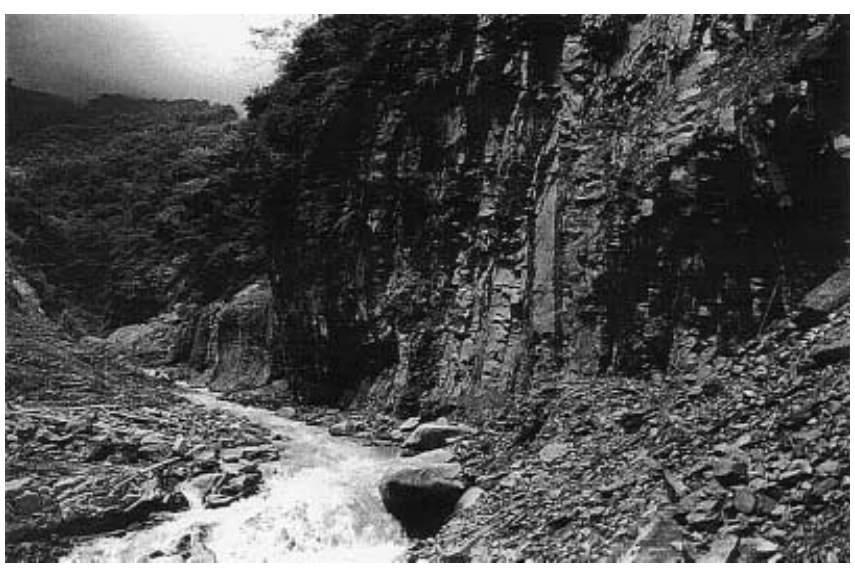

Fig. 14

Erosional features clearly appeared along both sides of No. 3 gully after typhoon Herb
Table 5

The results of safety factor for the accumulated deposits of No. 1 and No. 3 gullies. $D$ Dry condition, $S$ saturated condition, $\theta$ slope grade of gully, $\phi$ friction angle, $F$ safety factor

\begin{tabular}{|c|c|c|c|c|}
\hline Gully & Sample no. & $\begin{array}{l}\theta \\
\left(^{\circ}\right)\end{array}$ & $\begin{array}{l}\phi \\
\left(^{\circ}\right)\end{array}$ & $\mathrm{F}$ \\
\hline \multirow[t]{4}{*}{ No. 1} & $105 \mathrm{D}$ & 18.1 & 35.6 & 1.13 \\
\hline & $138 \mathrm{D}$ & 18.1 & 34.4 & 1.08 \\
\hline & $105 \mathrm{~S}$ & 18.1 & 31.3 & 0.96 \\
\hline & $138 \mathrm{~S}$ & 18.1 & 30.2 & 0.92 \\
\hline \multirow[t]{4}{*}{ No. 3} & $305 \mathrm{D}$ & 18.5 & 36.2 & 1.17 \\
\hline & 338D & 18.5 & 34.7 & 1.11 \\
\hline & $305 \mathrm{~S}$ & 18.5 & 31.1 & 0.96 \\
\hline & $335 \mathrm{~S}$ & 18.5 & 29.4 & 0.90 \\
\hline
\end{tabular}

\section{Stability results on gully deposits}

Under normal dry conditions in No. 1 gully, the safety factors (Fs) are 1.13 and 1.08. This means that the deposits in the valley are normally in a stable state. In the fully saturated situation, the safety factors fall to 0.96 and 0.92 , respectively. These materials deposited in the gully floor would then be in a highly unstable state.

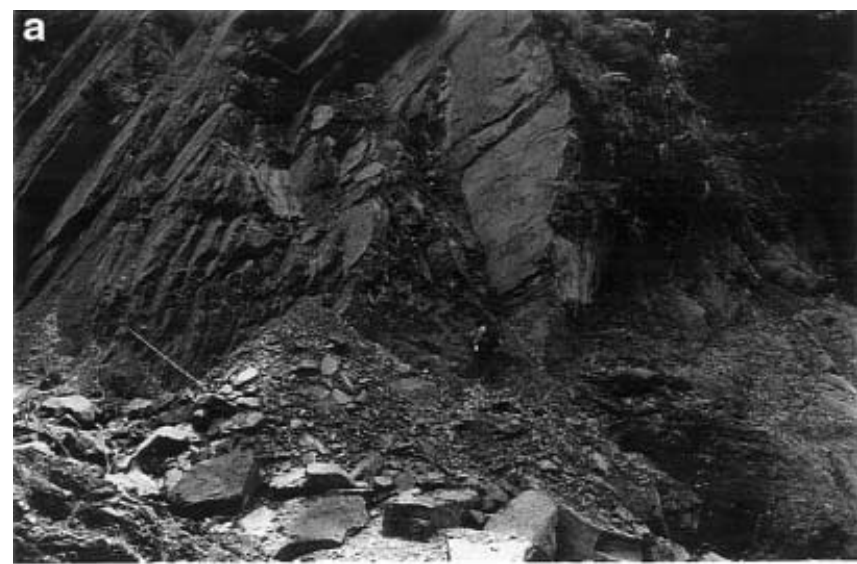

Plane failure model

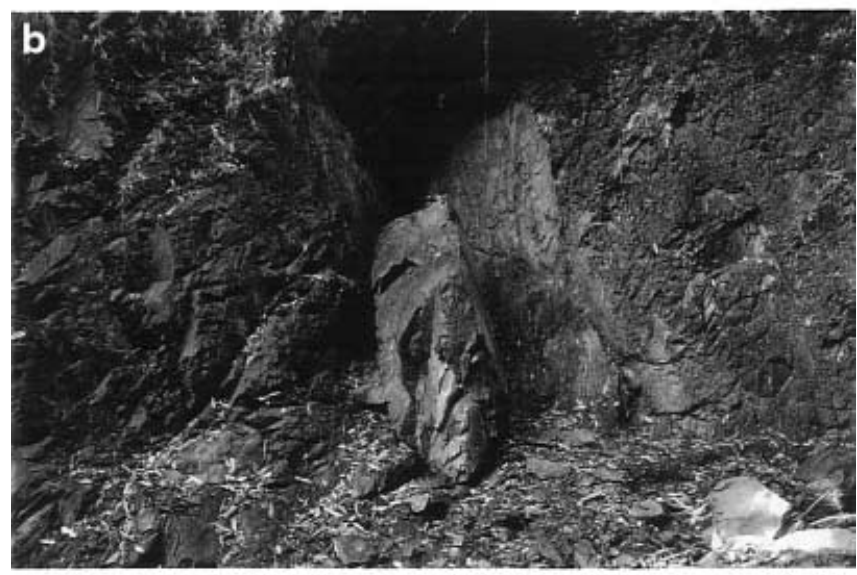

Wedge failure model

Fig. 15a, b

The failure models included $\mathbf{A}$ a plane failure, and $\mathbf{B}$ a wedge failure. Both failure models are obviously displayed on both sides of No. 1 and No. 3 gullies in the study area 
Under normal dry conditions in No. 3 gully, the safety factors (Fs) are 1.17 and 1.11. This means that the deposits in the valley are normally in a stable state. In the fully saturated situation, the safety factors fall to 0.96 and 0.90 , respectively. These materials deposited in the gully floor would then be in a highly unstable state.

\section{Discussion}

This paper describes the geometry of debris flow sources and provides a better understanding of these sources for gullies of the study area. However, regardless of the length of time of this accumulation, cohesion of the particles deposited in this manner appears to be quite weak to nonexistent.

The debris flow resulted from mixing of rock fragments, fine fractions and water moving down gullies with slope angles ranging from about 15 to $25^{\circ}$. Some experimental results demonstrated that precipitation would increase the water content, increasing pore-water pressure and decreasing the shear strength of the geomaterial (Sidle and Swanston 1982). Therefore, these deposits become, in effect, "loaded cannons" waiting for precipitation to trigger the debris flow and send a deluge rushing down the river bed, engulfing all in their path. Gully gradients in the source, flow and deposition areas are a result of the lack/ presence of confinement of the stream, and the ratio of the debris material to water ( $\mathrm{Wu}$ and Swanston 1980). Historically, relatively little debris flow material accumulated over the long time period of at least 15 years, as verified by aerial photographs spanning the 1980-1996 study period. The deposited rock fragments have a nearly equal axial ratio in their longitudinal and horizontal directions. Their shapes appeared subrounded to rounded, and their morphology remains rough. The topography of the gully is continually changing, but its destruction potential remains enormous.

\section{Conclusions}

The topography of the area is outlined, and the urgent necessity to study the debris flow hazards is identified. Prediction can be vital. Discontinuities can be a major factor in forming the accumulated deposits in the gullies. The accumulated deposits are the main source of the debris flow once the disaster is triggered.

To study the development of a debris flow, aerial photography is deemed essential. Based on field investigations and laboratory tests, it is demonstrated that debris flows are triggered and moved by high-intensity rainfall. The material is produced and supplied from both sides of gullies.

Acknowledgements We would like to thank Prof. S.W. Lee, Agriculture Ministry of Administrated Yuan, Dr. C.S. Wu, Development Bureau of Taipei City, Prof. M.L. Lin, Department of Civil Engineering, National Taiwan University, and
Dr. D. Dobyns, Department of Applied English, Ming Chuan University, for their constructive comments. Thanks are also extended to the National Science Council, Republic of China, for kind support under NSC grants 87-2116-M-002-027.

\section{References}

Baldwin JE II, Donley HF, Howard TR (1987) On debris flow/ avalanche mitigation and control, San Francisco Bay area, California. Geol Soc Am Rev Eng Geol II:223-236

Bromhead EN (1986) The stability of slope. Surrey University Press, New York

Campbell RH (1974) Debris flow originating from soil slips during rainstorms in southern California. Q J Eng Geol 7:339349

Chen $\mathrm{H}$ (2000) The geomorphological comparison of two debris flows and their triggering mechanisms. Bull Eng Geol Environ 58(4):297-308

Chen H, Chen RH, Lin ML (1999) Initiation of the Tungmen debris flow, Eastern Taiwan. J Environ Eng Geosci V(4):459-473

Chen RH, Lin ML, Chen H (1995) Mechanism of initiation of debris flow. In: Cheng FY, Shew MS (eds) Urban disaster mitigation. Elsevier, Oxford, pp 231-243

Costa JE, Jarrett RD (1981) Debris flows in small mountain stream channels of Colorado and their hydrologic implications. Bull Assoc Eng Geol 18:309-322

Eyles RJ (1979) Slip-triggering rainfalls in Wellington city, New Zealand. N Z J Sci 22(2):117-122

Fyleming RW, Ellen SD, Algu MA (1989) Transformation of dilative and contractive landslide debris into debris flows - an example from Martin County, California. Eng Geol 27:201-223 Graham J (1984) Methods of stability analysis. In: Brusden D, Prior DB (eds) Slope instability. Wiley, New York, pp 171-215

Ho CS (1986) An introduction to the geology of Taiwan: Explanatory of the geologic map of Taiwan. The Ministry of Economic Affairs, Republic of China

Hoek E, Bray J (1981) Rock slope engineering. The Institution of Mining and Metallurgy, London

Johnson AM, Rodine JR (1984) Debris flow. In: Brunsden D, Prior D (eds) Slope instability. Wiley, New York, pp 257-361

Nielsen HP (1984) Geology, rainfall and groundwater associated with several debris flows in Santa Cruz County, California. MSc Thesis, University of California at Santa Cruz

Priest SD (1992) Discontinuity analysis for rock engineering. Chapman and Hall, London

Rib HT, Liang T (1978) Recognition and identification. In: Schuster RL, Krizek RJ (eds) Landslides analysis and control. National Academy of Sciences, Washington, DC, Spec Rep $176: 34-80$

Selby MJ (1987) Rock slopes. In: Anderson MG, Richards KS (eds) Slope stability. Wiley, New York, pp 475-504

Shlemon RJ, Wright RH, Montgomery DR (1987) Anatomy of a debris flow, Pacifica, California. Geol Soc Am Rev Eng Geol VII:181-199

Sidle RC, Swanston DN (1982) Analysis of a small debris flow in coastal Alaska. Can Geotech J 19(2):167-174

Su DY (1998) The mechanism study of debris flow along the Hoser River in Nantou (in Chinese). MSc Thesis, National Taiwan University

Takahashi T (1991) Debris flow. IAHR Balkema, Rotterdam VanDine DF (1985) Debris flow and debris torrents in the Southern Canadian Cordillera. Canada Geotech J 22:44-62 Wu TH, Swanston DN (1980) Risk of landslides in shallow soils and its relation to cutting in southeastern Alaska. Forest Sci 26(3):495-510 